\title{
Plant Protection Research
}

http:/www.journals.zu.edu.eg/journalDisplay.aspx?Journalld=1\&queryType=Master

\section{EFFECT OF SOME CHEMICAL CONSTITUENTS OF CERTAIN CITRUS TREE HOSTS ON THE POPULATION DENSITY OF Aonidiella aurantii (Maskell) AND Chrysomphalus aonidum (L.) AND THEIR POPULATION FLUCTUATIONS}

\author{
Asmaa M. Abd-EIghaffar", Gamila Sh. Selem, I.M. Kelany and Shadia M. Omara \\ Plant Prot. Dept., Fac. Agric., Zagazig Univ., Egypt
}

Received: 26/04/2017 ; Accepted: 06/08/2017

\begin{abstract}
This investigation was carried out to study the effect of some chemical constituents (total phenols, total carbohydrates, total proteins and $\mathrm{pH}$ values) of three citrus tree host leaves (sweet orange, navel orange and mandarin) on the population density of Aonidiella aurantii (Maskell) and Chrysomphalus aonidum (L.) in relation with prevailing temperature and relative humidity in different citrus orchards at Minia Alkamh district, Sharkia Governorate, Egypt during two successive years extended from December 2012 to November 2014. The results showed that sweet orange appeared to be the most susceptible citrus tree hosts to infestation by the scale insects followed by navel orange and mandarin at the least. The population density of $A$. aurantii had three peaks on the three citrus tree hosts in the two years. Also, C. aonidum recorded three peaks on the navel orange in the two years, while on sweet orange indicated four peaks occurred during the first year and three peaks of densities were obtained during the second one. On mandarin trees, three and four peaks were observed in the aforementioned years, respectively. The highest population was exhibited by A.aurantii in the first peak by 636 insects/300 leaves on sweet orange on February in the second year while, it was recorded by $C$. aonidum in the third peak by 59 insects/300 leaves on October in the same year. There was a positive relationship between both of total carbohydrates and total proteins and the population density of $A$. aurantii and C. aonidum on sweet orange, navel orange and mandarin, while no relation was found between each of total phenols and $\mathrm{pH}$ values and the infestation level by the two scale insects.
\end{abstract}

Key words: Citrus tree hosts, Aonidiella aurantii, Chrysomphalus aonidum, population density, chemical constituents.

\section{INTRODUCTION}

Citrus is one of the most important fruit crops in the world and ranked first among fruit crops in Egypt. Citrus plantations are among the most important horticultural crops in Egypt especially grown for export of their fruits (Tawfeek, 2012). The cultivated area with citrus in Egypt has enormously increased through the last decades reaching about 530415 fad. The fruiting area reached 440706 fad., producing about 4402180 tons with a mean of 10.42 tons/ fad., (Statistics of the Ministry of Agriculture, 2014). Citrus fruits contain a variety of vitamins, minerals, fiber, and phytochemicals such as carotenoids, flavonoids, and limonoids, which

\footnotetext{
*Corresponding author: Tel.: +201145603880

E-mail address: asmaaalhady2022@yahoo.com
}

appear to have biological activities and health benefits. There is considerable evidence that citrus fruit have antioxidant and antimutagenic properties and positive associations with bone, cardiovascular and immune system health (Turner and Burri, 2013).

Citrus trees are at risk of sustaining damage by scale insects infestation. Scales derive their name from the shell-like, protective covering they form over themselves (Wawrzynski and Ascerno, 2009). Scale insects damage citrus trees by extracting vital fluids from the tree, resulting in poor fruit quality and tree health. Habib et al. (1971), Darwish (1976), AbdElfattah et al. (1978), Amin and Salem (1978), El-Rahman et al. (1979), El-Nabawi et al. 
(1986), El-Nabawi and Ammar (1987), Farag et al. (1990) and Tawfeek (2007) reported that infestation of citrus by red scale insect Aonidiella aurantii (Maskell) depends largely on the size of infestation in November. Population fluctuations of Aonidiella aurantii and Chrysomphalus aonidum (L.) were studied by many authors (Hafez et al., 1970; Salman, 1970; Abul-Nasr et al., 1975; Abul-Nasr et al.,1977; El-Deeb et al., 1992; Selim, 1993; Morsi, 1999). The aim of this work was study the effect of some chemical constituents of certain citrus tree hosts on the population densities of $A$. aurantii and C. aonidum as well as their population fluctuations.

\section{MATERIALS AND METHODS}

\section{Population Fluctuations of Some Scale Insects Infesting Certain Citrus Tree Hosts}

These experiments were carried out at Minia Alkamh district, Sharkia Governorate during the two successive years during the period between December 2012 to November 2014 in citrus orchards about 20 faddans area (more than 12 years old) to study the population fluctuations of two scale insects Aonidiella aurantii (Maskell) and Chrysomphalus aonidum (L.) on certain citrus tree hosts. This farm was cultivated with citrus tree hosts (sweet orange, navel orange and mandarin) which received normal agricultural practices and no chemical control was applied. One faddan was selected for each citrus tree hosts. Three citrus trees were selected in each tree host which nearly similar in size and vegetation. The plant sample technique (25 leaves) was used for collecting the main two scale insects $A$. aurantii and $C$. aonidum which infesting sweet orange, navel orange and mandarin trees from the main directions (north, south, east and west) and inner during the period from December 2012 to November 2014. Weekly samples were put in paper bags and transferred to the laboratory in the same day for examination and counting the number of the two scale insects $A$. aurantii and $C$. aonidum by the aid of stereoscopic microscope and the peaks were recorded. The daily means of minimum, maximum temperature and relative humidity were obtained from the Meteorological Department of the Agricultural Research Station at Sharkia Governorate. The records of these factors were recalculated to get the daily averages within a month. The obtained data were statistically analysed according to Costat Software Microcomputer Program (Anonymous, 1990).

\section{Chemical Analysis of Certain Citrus Tree Host Leaves}

Samples of citrus tree host leaves were collected from the investigated citrus trees to determine some chemical constituents. Total phenols were determined according to the method described by Song et al. (2010). Total nitrogen was estimated according to Bremner and Mulvaney (1982). Total protein constituents were calculated by multiplying crude nitrogen percentage by the conversion factor 6.25 . Total carbohydrates in leaves were determined by colorimetrically using the anthrone reagent and the color intensity was measured at $240 \mathrm{mu}$ following the method described by Dubois et al. (1956). pH value was estimated in plant sap using $\mathrm{pH}$ meter (Feldman, 1956).

\section{RESULTS AND DISCUSSION}

\section{Population Density of Some Scale Insects Aonidiella aurantii (Maskell) and Chysomphalus aonidum (L.) Infesting Certain Citrus Tree hosts}

Results in Table 1 show the annual total number of $A$. aurantii and $C$. aonidum infesting some citrus tree hosts (sweet orange, navel orange and mandarin) at Minia Alkamh district, Sharkia Governorate, Egypt during the two successive years from December 2012 to November 2014. The annual total numbers of both scale insects $A$. aurantii and $C$. aonidum recorded higher level of densities in the second year of investigation than in the first one. Population densities of $A$. aurantii were higher than $C$. aonidum on the three citrus tree hosts during the two years of study. A. aurantii had the highest annual total number (2550 and 3070 insects) and C. aonidum recorded 244 and 291 insects on sweet orange in the two years of study, respectively. Generally, it is clear that the highest population density of the aforementioned scale insects in the two years was recorded on sweet orange by a total number of 6155 insects followed descendingly by 1388 insects on navel 
Table 1. Annual total number of $A$. aurantii and $C$. aonidum infesting certain citrus trees at Minia Alkamh district, Sharkia Governorate during two years from December 2012 to November 2014

\begin{tabular}{|c|c|c|c|c|c|c|c|}
\hline \multirow[t]{3}{*}{ Citrus tree host } & \multicolumn{7}{|c|}{ Annual total number of scale insects } \\
\hline & \multicolumn{3}{|c|}{$2012 / 2013$} & \multicolumn{3}{|c|}{$2013 / 2014$} & \multirow{2}{*}{$\begin{array}{c}\text { General } \\
\text { total }\end{array}$} \\
\hline & $\begin{array}{c}A . \\
\text { aurantii }\end{array}$ & $\begin{array}{c}C . \\
\text { aonidum }\end{array}$ & $\begin{array}{c}\text { Total } \\
\text { number }\end{array}$ & $\begin{array}{c}A . \\
\text { aurantii }\end{array}$ & $\begin{array}{c}C . \\
\text { aonidum }\end{array}$ & $\begin{array}{c}\text { Total } \\
\text { number }\end{array}$ & \\
\hline Sweet orange & 2550 & 244 & 2794 & 3070 & 291 & 3361 & 6155 \\
\hline Navel orange & 514 & 101 & 615 & 646 & 127 & 773 & 1388 \\
\hline Mandarin & 325 & 38 & 363 & 416 & 76 & 492 & 855 \\
\hline $\mathbf{F}$ & $314.36^{* *}$ & 13.01 & & $1845.81^{* *}$ & $19.57^{*}$ & & \\
\hline
\end{tabular}

Tabulated $\mathrm{F}$ values $0.05=19.01$ and $0.01=99.14$

orange and 855 insects on mandarin. Statistical analysis of data showed that there were highly significant differences between the population density of A. aurantii on different citrus tree hosts in the two years of study. While in case of C. aonidum there were insignificant differences in the first year and significant differences in the second one. These results agree with those obtained by Tawfeek (2012) who found that the highest mean numbers of Parlatoria ziziphi on the upper surface of leaves was recorded on sweet orange (398.9 individuals/ leaf), navel orange (270.0 individuals/leaf) and mandarin (159.2 individuals/ leaf).

\section{Effect of Some Chemical Constituents of Certain Citrus Tree Host Leaves on the Population Density of Scale Insects, $A$. aurantii and $C$. aonidum}

Results presented in Table 2 show the relationship between some chemical constituents of citrus tree hosts (sweet orange, navel orange and mandarin) and the population density of A. aurantii and C. aonidum at Minia Alkamh district, Sharkia Governorate during the period between December 2013 and November 2014. The results cleared that there were highly significant differences between the total phenols, total carbohydrates, total proteins and $\mathrm{pH}$ values in the three citrus hosts. Also, there were highly significant differences between the population density of $A$. aurantii while, in case of $C$. aonidum there were significant differences on different citrus hosts. From these results it is clear that there is a positive relationship between chemical constituents (total carbohydrates and total proteins) and the population density of $A$. aurantii and $C$. aonidum on sweet orange, navel orange and mandarin. The highest infestation by the two scale insects were recorded on sweet orange (3361 insects) with a mean total carbohydrates $(11.77 \%)$ and total proteins $(10.56 \%)$ followed by navel orange (773 insects) and mandarin (492 insects) with a mean of total carbohydrates $(8.81 \%$ and $7.94 \%)$ and total proteins $(6.09 \%$ and $4.10 \%)$, respectively. The obtained results are in agreement with the findings of Abo-Alnour et al. (2016) who found that there were positive relationships between chemical constituents (total carbohydrates and total proteins) and the population density of aphid, leafhopper and whitefly insects infesting some citrus tree hosts

In respect of total phenols and $\mathrm{pH}$ values, results in Table 2 appear that no clear relation was found between each of total phenols or $\mathrm{pH}$ values and the infestation by $A$. aurantii or $C$. aonidum. These results disagree with those of Abo-Alnour et al. (2016) who mentioned that there were reverse correlation between total phenol and $\mathrm{pH}$ values and the population density of aphid, leafhopper and whitefly insects infesting some citrus tree hosts. 
Table 2. Effect of some chemical constituents of certain citrus tree host leaves on scale insects, $A$. aurantii and $C$. aonidum at Minia Alkamh district, Sharkia Governorate during the second year 2013/2014

\begin{tabular}{|c|c|c|c|c|c|c|c|}
\hline \multirow[t]{2}{*}{ Citrus tree host } & \multicolumn{4}{|c|}{ Chemical constituent } & \multicolumn{2}{|c|}{$\begin{array}{c}\text { Total number of } \\
\text { scale insects }\end{array}$} & \multirow{2}{*}{$\begin{array}{c}\text { General total } \\
\text { number of } \\
\text { scale insects }\end{array}$} \\
\hline & $\begin{array}{c}\text { Mean of total } \\
\text { phenols } \\
\text { (mg GA/gdw) }\end{array}$ & $\begin{array}{c}\text { Mean of total } \\
\text { carbohydrates } \\
(\mathrm{mg} / \mathrm{dl})\end{array}$ & $\begin{array}{c}\text { Mean of total } \\
\text { proteins } \\
\text { (mg/dl) }\end{array}$ & $\begin{array}{c}\mathrm{pH} \\
\text { value }\end{array}$ & $\begin{array}{c}A . \\
\text { aurantii }\end{array}$ & $\begin{array}{c}C . \\
\text { aonidum }\end{array}$ & \\
\hline Sweet orange & 2.00 & 11.77 & 10.56 & 6.18 & 3070 & 291 & 3361 \\
\hline Navel orange & 0.21 & 8.81 & 6.09 & 6.07 & 646 & 127 & 773 \\
\hline Mandarin & 5.00 & 7.94 & 4.10 & 6.25 & 416 & 76 & 492 \\
\hline $\mathbf{F}$ & $2458.70^{* *}$ & $7532.78^{* *}$ & $7086.97^{* *}$ & $159.76^{* *}$ & $1845.81^{* *}$ & $19.57^{*}$ & \\
\hline
\end{tabular}

Tabulated $\mathrm{F}$ values $0.05=19.01$ and $0.01=99.14$

\section{Population Fluctuations of Certain Scale Insects}

\section{California red scale insect, $A$. aurantii}

The monthly total numbers of $A$. aurantii during the two investigated years are recorded in Tables 3 and 4.

Three peaks of population density were obtained during the two years of study with a big population in the second year on the three citrus tree hosts. In the first year, three peaks occurred on February, June and September on sweet orange and navel orange with a monthly total number of 603,99 and 244 insects and 88, 53 and 76 insects/300 leaves at 14.4, 26.0 and $24.5^{\circ} \mathrm{C}$ with $82.8 \%, 65.4 \%$ and $65.8 \% \mathrm{RH}$, respectively (Table 3). Also, three peaks on mandarin occurred on February, June and October in the first year with monthly total number of 55, 18 and 58 insects $/ 300$ leaves at $14.4,26.0$ and $24.1^{\circ} \mathrm{C}$ with $82.8 \%, 65.4 \%$ and $66.3 \% \mathrm{RH}$, respectively. In the second year of study, the three peaks occurred on February, June and October on sweet orange and navel orange with a monthly total number of 636, 135,285 insects $/ 300$ leaves and 110, 71, 67 insects at $15.7,27.9$ and $23.9^{\circ} \mathrm{C}$ with $61.3 \%$, $34.5 \%$ and $53.9 \% \mathrm{RH}$, respectively (Table 4 ). In case of mandarin the three peaks occurred January, May and October with monthly total number of 66, 29 and 56 insects/300 leaves at $15.1,25.4$ and $23.9^{\circ} \mathrm{C}$ with $59.9 \%, 39.9 \%$ and $53.9 \% \mathrm{RH}$, respectively. These results are in agreement with those obtained by some authors such as Habib et al. (1971) who recorded that $A$. aurantii had 3-4 generations. Kamel (2010) studied the population density of the citrus red scale, $A$. orientalis infesting navel orange leaves in 7 Governorates of Lower Egypt and found that the insect had 3-4 annual population peaks. Moustafa (2012) added that the populations of red scale insect had two peaks, the first peak occurred on April and the second one on October.

\section{Citrus black scale insect, $C$. aonidum}

Results given in Tables 3 and 4 show the population fluctuations of $C$. aonidum on the aforementioned three tested citrus tree hosts, (sweet orange, navel orange and mandarin). During the first year (2012/2013) four peaks were noticed on sweet orange with monthly total number of $26,15,47$ and 41 insects/300 leaves on January, March, June and September at means of $13.1,17.4,26.0$ and $24.5^{\circ} \mathrm{C}$ and with $84.2 \%, 77.8 \%, 65.4 \%$ and $65.8 \% \mathrm{RH}$, respectively (Table 3). On the other hand, three peaks of population density with relatively low numbers were noticed for $C$. aonidum on navel orange on February, July and September with a monthly total numbers of 16,12 and 22 insects/300 leavs at $14.4,26.5$ and $24.5^{\circ} \mathrm{C}$ and with $82.8 \%, 66.0 \%$ and $65.8 \% \mathrm{RH}$, respectively, while on mandarin on January, July and September with a small monthly total number of 3,10 and 8 insecs $/ 300$ leaves at $13.1,26.5$ and $24.5^{\circ} \mathrm{C}$ with $84.2 \%$, $66.0 \%$ and $65.8 \% \mathrm{RH}$, successively. In the second year (2013/2014) three peaks occurred on January, June and October with monthly total 
Table 3. Annual abundance of certain scale insects $A$. aurantii and $C$. aonidum on navel orange, sweet orange and mandarin at Minia Alkamh district, Sharkia Governorate during the first year from December 2012 to November 2013

\begin{tabular}{|c|c|c|c|c|c|c|c|c|c|c|c|c|}
\hline \multirow[t]{3}{*}{ Date (month) } & \multicolumn{9}{|c|}{ Monthly total number of scale insects/300 leaves } & \multirow{3}{*}{$\begin{array}{c}\text { General } \\
\text { total }\end{array}$} & \multicolumn{2}{|c|}{ Mean } \\
\hline & \multicolumn{3}{|c|}{ Sweet orange } & \multicolumn{3}{|c|}{ Navel orange } & \multicolumn{3}{|c|}{ Mandarin } & & Temp. & RH \\
\hline & $\begin{array}{c}A . \\
\text { aurantii } \\
\end{array}$ & $\begin{array}{c}C . \\
\text { aonidum } \\
\end{array}$ & $\begin{array}{c}\text { Total } \\
\text { number }\end{array}$ & $\begin{array}{c}A . \\
\text { aurantii }\end{array}$ & $\begin{array}{c}C . \\
\text { aonidum } \\
\end{array}$ & $\begin{array}{c}\begin{array}{c}\text { Total } \\
\text { number }\end{array} \\
\end{array}$ & $\begin{array}{c}A . \\
\text { aurantii } \\
\end{array}$ & $\begin{array}{c}C . \\
\text { aonidum }\end{array}$ & $\begin{array}{c}\begin{array}{c}\text { Total } \\
\text { number }\end{array} \\
\end{array}$ & & & \\
\hline Dec. 2012 & 167 & 10 & 177 & 33 & 2 & 35 & 27 & 1 & 28 & 240 & 14.8 & 63.6 \\
\hline Jan. 2013 & 379 & 26 & 405 & 59 & 4 & 63 & 49 & 3 & 52 & 520 & 13.1 & 84.2 \\
\hline Feb. & 603 & 13 & 616 & 88 & 16 & 104 & 55 & 0 & 55 & 775 & 14.4 & 82.8 \\
\hline Mar. & 309 & 15 & 324 & 50 & 5 & 55 & 11 & 1 & 12 & 391 & 17.4 & 77.8 \\
\hline Apr. & 163 & 4 & 167 & 16 & 2 & 18 & 3 & 1 & 4 & 189 & 19.3 & 69.1 \\
\hline May & 9 & 7 & 16 & 13 & 3 & 16 & 6 & 3 & 9 & 41 & 25.0 & 62.4 \\
\hline June & 99 & 47 & 146 & 53 & 10 & 63 & 18 & 4 & 22 & 231 & 26.0 & 65.4 \\
\hline Jul. & 80 & 22 & 102 & 21 & 12 & 33 & 15 & 10 & 25 & 160 & 26.5 & 66.0 \\
\hline Aug. & 147 & 29 & 176 & 21 & 9 & 30 & 30 & 2 & 32 & 238 & 26.6 & 66.6 \\
\hline Sep. & 244 & 41 & 285 & 76 & 22 & 98 & 32 & 8 & 40 & 423 & 24.5 & 65.8 \\
\hline Oct. & 200 & 22 & 222 & 45 & 14 & 59 & 58 & 4 & 62 & 343 & 24.1 & 66.3 \\
\hline Nov. & 150 & 8 & 158 & 39 & 2 & 41 & 21 & 1 & 22 & 221 & 19.7 & 67.15 \\
\hline Total number & 2550 & 244 & 2794 & 514 & 101 & 615 & 325 & 38 & 363 & & & \\
\hline General mean & 212.50 & 20.33 & & 42.83 & 8.42 & & 27.08 & 3.17 & & & & \\
\hline
\end{tabular}

Table 4. Annual abundance of certain scale insects $A$. aurantii and $C$. aonidum on navel orange, sweet orange and mandarin at Minia Alkamh district, Sharkia Governorate during the second year from December 2013 to November 2014

\begin{tabular}{|c|c|c|c|c|c|c|c|c|c|c|c|c|}
\hline \multirow[t]{3}{*}{ Date (month) } & \multicolumn{9}{|c|}{ Monthly total number of scale insects/300 leaves } & \multirow{3}{*}{$\begin{array}{c}\text { General } \\
\text { total }\end{array}$} & \multicolumn{2}{|c|}{ Mean } \\
\hline & \multicolumn{3}{|c|}{ Sweet orange } & \multicolumn{3}{|c|}{ Navel orange } & \multicolumn{3}{|c|}{ Mandarin } & & Temp. & . RH \\
\hline & $\begin{array}{c}A . \\
\text { aurantii } \\
\end{array}$ & $\begin{array}{c}C . \\
\text { aonidum } \\
\end{array}$ & $\begin{array}{c}\text { Total } \\
\text { number }\end{array}$ & $\begin{array}{c}A . \\
\text { aurantii } \\
\end{array}$ & $\begin{array}{c}C . \\
\text { aonidum } \\
\end{array}$ & $\begin{array}{c}\begin{array}{c}\text { Total } \\
\text { number }\end{array} \\
\end{array}$ & $\begin{array}{c}A . \\
\text { aurantii } \\
\end{array}$ & $\begin{array}{c}C . \\
\text { aonidum } \\
\end{array}$ & $\begin{array}{c}\text { Total } \\
\text { number } \\
\end{array}$ & & & \\
\hline Dec. 2013 & 158 & 14 & 172 & 30 & 4 & 34 & 33 & 6 & 39 & 245 & 19.6 & 64.9 \\
\hline Jan. 2014 & 422 & 33 & 455 & 77 & 12 & 89 & 66 & 11 & 77 & 621 & 15.1 & 59.9 \\
\hline Feb. & 636 & 25 & 661 & 110 & 9 & 119 & 62 & 2 & 64 & 844 & 15.7 & 61.3 \\
\hline Mar. & 351 & 20 & 371 & 75 & 11 & 86 & 44 & 8 & 52 & 509 & 18.8 & 48.7 \\
\hline Apr. & 255 & 12 & 267 & 31 & 6 & 37 & 15 & 0 & 15 & 319 & 22.2 & 46.4 \\
\hline May & 112 & 15 & 127 & 37 & 9 & 46 & 29 & 1 & 30 & 203 & 25.4 & 39.9 \\
\hline June & 135 & 24 & 159 & 71 & 12 & 83 & 13 & 7 & 20 & 262 & 27.9 & 34.5 \\
\hline July & 123 & 23 & 146 & 31 & 12 & 43 & 18 & 6 & 24 & 213 & 28.8 & 53.6 \\
\hline Aug. & 196 & 28 & 224 & 30 & 13 & 43 & 27 & 8 & 35 & 302 & 29.6 & 54.5 \\
\hline Sep. & 274 & 31 & 305 & 64 & 15 & 79 & 42 & 8 & 50 & 434 & 28.5 & 50.8 \\
\hline Oct. & 285 & 59 & 344 & 67 & 21 & 88 & 56 & 17 & 73 & 505 & 23.9 & 53.9 \\
\hline Nov. & 123 & 7 & 130 & 23 & 3 & 26 & 11 & 2 & 13 & 169 & 19.7 & 58.7 \\
\hline Total number & 3070 & 291 & 3361 & 646 & 127 & 773 & 416 & 76 & 492 & & & \\
\hline General mean & 255.83 & 24.25 & & 53.83 & 10.58 & & 34.67 & 6.33 & & & & \\
\hline
\end{tabular}


number of 33, 24 and 59 insects/300 leaves on sweet orange at $15.1,27.9$ and $23.9^{\circ} \mathrm{C}$ with $59.9 \%, 34.5 \%$ and $53.9 \% \mathrm{RH}$, respectively (Table 4). In respect to navel orange, three peaks were noticed on January, March and October with monthly total number of 12,11 and 21 insects/300 leaves at $15.1,18.8$ and $23.9^{\circ} \mathrm{C}$ with $59.9 \%, 48.7 \%$ and $53.9 \% \mathrm{RH}$, consecutively. On the other hand, four peaks with a low density occurred on mandarin on January, March, June and October with monthly total numbers of 11 , 8,7 and 17 insects/300 leaves at $15.1,18.8,27.9$ and $23.9^{\circ} \mathrm{C}$ with $59.9 \%, 48.7 \%, 34.5 \%$ and $53.9 \% \mathrm{RH}$, respectively. The results are partially in harmony with the findings of Moustafa (2012) who mentioned that, the black scale insect $C$. aonidum population reached maximum numbers during May (1826 and 1747/ 30 leaves and 15 twigs) in first and second years, respectively.

Effect of Some Weather Factors on the Population Density of $A$. aurantii and $C$. aonidum Infesting Certain Citrus Tree Hosts During the Two Years of 2012/2013 and 2013/ 2014

Results presented in Table 5 show the simple correlation (r), simple partial regression coefficient (b) and coefficient of determination $(\mathrm{CD} \%)$ for the relationship between the monthly mean temperature, monthly mean relative humidity and the population density of certain scale insects attacking citrus tree hosts during the two successive years 2012/2013 and 2013/ 2014.

\section{A. aurantii}

Statistical analysis of the obtained data showed that the correlation coefficient between the activity of $A$. aurantii population and mean temperature was negative and significant $\left(\mathrm{r}_{1}=\right.$ $-0.701^{*}$ and $\left.-0.643^{*}\right)$ on sweet orange, while it was insignificant $\left(\mathrm{r}_{1}=-0.399\right.$ and -0.426$)$ on navel orange and mandarin $\left(\mathrm{r}_{1}=-0.305\right.$ and -0.540$)$, respectively during the two investigated years (Table 5). Concerning the correlation between A. aurantii population and relative humidity, there were positive and highly significant correlations on sweet orange $\left(\mathrm{r}_{2}=0.875^{* * *}\right)$ and significant on navel orange $\left(r_{2}=0.591^{*}\right)$, while on mandarin it was positive and insignificant $\left(\mathrm{r}_{2}\right.$ $=0.451$ ), in the first year of study. In the second one, these values were positive and insignificant $\left(\mathrm{r}_{2}=0.389,0.026\right.$ and 0.442$)$ on sweet orange, navel orange and mandarin, consecutively.

There were negative and insignificant partial regressions between the population densities of A. aurantii and mean temperature $\left(b_{1}=-0.146\right.$ and -0.610 on sweet orange $),\left(b_{1}=0.056\right.$ and -0.579 on navel orange $)$ and $\left(b_{1}=0.040\right.$ and -0.426 on mandarin) during 2012/2013 and 2013/2014, respectively (Table 5). Partial regressions between the population densities of $A$. aurantii and the mean relative humidity were in general positive and insignificant $\left(b_{2}=0.770\right.$ and 0.061 on sweet orange), $\left(b_{2}=0.631\right.$ and -0.285 on navel orange) and $\left(b_{2}=0.480\right.$ and 0.213 on mandarin) during 2012/2013 and 2013/2014, respectively.

Means of both temperature and relative humidity affected $A$. aurantii population by $77.60 \%$ and $41.60 \%$ on sweet orange, $35.10 \%$ and $24.00 \%$ on navel orange and $20.40 \%$ and $32.40 \%$ on mandarin during 2012/2013 and 2013/2014, respectively (Table 5).

\section{C. aonidum}

There were positive and insignificant correlations between the mean number of C. aonidum and mean temperature in both years, whereas $\mathrm{r}_{1}=0.450$ and 0.140 on sweet orange and $r_{1}=0.355$ and 0.395 on navel orange, while it was positive and significant on mandarin $\mathrm{r}_{1}=0.607^{*}$ in the first year and insignificant in the second one $\left(r_{1}=0.098\right)$. Relative humidity showed negative and positive insignificant effects on the population of $C$. aonidum, with $\mathrm{r}_{2}$ values of -0.082 and 0.070 on sweet orange and 0.023 and -0.203 on navel orange and -0.350 and 0.146 on mandarin in the two years of study, respectively (Table 5).

There were positive and insignificant partial regression coefficients between the population density of $C$. aonidum and mean temperature $\left(b_{1}=0.813\right.$ and 0.294 on sweet orange, 0.764 and 0.402 on navel orange and 0.736 and 0.248 on mandarin, for the two investigated years, successively. Concerning relative humidity, there were positive insignificant partial regression coefficients between mean relative humidity and the population density of $C$. aonidum on sweet orange, navel orange and mandarin $\left(b_{2}=0.503\right.$ and $0.204,0.573$ and 0.013 and 0.180 and 0.279$)$ in the two investigated years, respectively (Table 5). 
Table 5. Simple correlation coefficient ( $r$ ), partial regression coefficient (b) and coefficient of determination $(\mathrm{CD} \%)$ between some weather factors and the population density of certain scale insects on sweet orange, navel orange and mandarin at Minia Alkamh district, Sharkia Governorate during the two years from December 2012 to November 2014

\begin{tabular}{|c|c|c|c|c|c|c|c|c|c|c|c|}
\hline \multirow[t]{3}{*}{ Insect pest } & \multirow[t]{3}{*}{ Citrus tree hosts } & \multicolumn{4}{|c|}{ Simple correlation coefficient } & \multicolumn{4}{|c|}{ Partial regression coefficient } & \multirow{2}{*}{\multicolumn{2}{|c|}{$\begin{array}{c}\text { Total CD } \\
(\%)\end{array}$}} \\
\hline & & \multicolumn{2}{|c|}{$\mathbf{r}_{1}$} & \multicolumn{2}{|c|}{$\mathbf{r}_{2}$} & \multicolumn{2}{|c|}{$\mathbf{b}_{1}$} & \multicolumn{2}{|c|}{$\mathbf{b}_{2}$} & & \\
\hline & & $\begin{array}{l}2012- \\
2013\end{array}$ & $\begin{array}{l}2013- \\
2014\end{array}$ & $\begin{array}{l}2012- \\
2013\end{array}$ & $\begin{array}{l}2013- \\
2014\end{array}$ & $\begin{array}{l}2012- \\
2013\end{array}$ & $\begin{array}{l}\text { 2013- } \\
2014\end{array}$ & $\begin{array}{l}2012- \\
2013\end{array}$ & $\begin{array}{l}\text { 2013- } \\
2014\end{array}$ & $\begin{array}{l}2012- \\
2013\end{array}$ & $\begin{array}{l}2013- \\
2014\end{array}$ \\
\hline \multirow{3}{*}{ A. aurantii } & Sweet orange & $-0.701^{*}$ & $-0.643^{*}$ & $0.875^{* *}$ & 0.389 & -0.146 & -0.610 & 0.770 & 0.061 & 77.60 & 41.60 \\
\hline & Navel orange & -0.399 & -0.426 & $0.591 *$ & 0.026 & 0.056 & -0.579 & 0.631 & -0.285 & 35.10 & 24.00 \\
\hline & Mandarin & -0.305 & -0.540 & 0.451 & 0.442 & 0.040 & -0.426 & 0.480 & 0.213 & 20.40 & 32.40 \\
\hline \multirow{3}{*}{ C. aonidum } & Sweet orange & 0.450 & 0.140 & -0.082 & 0.070 & 0.813 & 0.294 & 0.503 & 0.204 & 32.50 & 4.90 \\
\hline & Navel orange & 0.355 & 0.395 & 0.023 & -0.203 & 0.764 & 0.402 & 0.573 & 0.013 & 28.10 & 15.60 \\
\hline & Mandarin & $0.607^{*}$ & 0.098 & -0.350 & 0.146 & 0.736 & 0.248 & 0.180 & 0.279 & 38.40 & 6.50 \\
\hline
\end{tabular}

Both temperature and relative humidity affected $C$. aonidum population by $32.50 \%$, $28.10 \%$ and $38.40 \%$ in the first year and 4.90 , $15.60 \%$ and $6.50 \%$ in the second one on sweet orange, navel orange and mandarin, successively (Table 5).

\section{REFERENCES}

Abd-Elfattah, M., A. El-Minshawy and E. Darwish (1978). The seasonal abundance of two scale insects, Lepidosaphes beckii (New.) and Aonidiella aurantii (Maskell.) infesting citrus trees in Egypt. Proc. $4^{\text {th }}$ Conf. Pest Control, NRC, Cairo, 1: 78-84.

Abo-Alnour, F.A.I., O.I.M. Hegab, A.M. Hegab and A.A. Abd-Elsamad (2016). Ecological studies on some homopterous insects infesting certain citrus and guava trees. Zagazig J. Agric. Res., 43 (5): 1705-1722.

Abul-Nasr, S., S. Swailem and N.M. Ahmed (1975). Seasonal fluctuations of the citrus red scale insect, Aonidiella aurantii (Maskell) in certain regions of Lower Egypt (Hemiptera:
Homop.: Diaspididae). Agric. Res. Rev., 33 (1): 149-159.

Abul-Nasr, S., S. Swailem and N.M. Ahmed (1977). Population studies on the Egyptian citrus scale insect, Chrysomphalus ficus Ashmead in different regions (Hemiptera: Homop. : Diaspididae). Agric. Res. Rev., 35 (1): 127-137.

Amin, A.H. and Y.S. Salem (1978). Population studies on scale insect tree hosts Parlatoria ziziphus, a new pest of citrus trees in Egypt (Homoptera, Coccoidea, Diaspididae). Proceedings of the $4^{\text {th }}$ Conference of Pest Control, 30 September to 3 October, Cairo, Egypt, 49-56.

Anonymous (1990). Costat Software Microcomputer Program; Version 4-20, Cohort Software, Berkley CA, USA.

Bremner, J.M. and C.S. Mulvaney (1982). Total Nitrogen. In (Page, A.L.; R.H. Miller and D.R. Keeney Eds.). Methods of Soil Analysis, Part 2 Ame. Soc. Agron. Masison., WIWSA. 
Darwish, E.T.E. (1976). Biological and control studies on the scale insects attacking citrus trees in Monoufia province. M.Sc. Thesis, Fac. Agric., Menoufia Univ., Egypt.

Dubois, M., K.A. Giles, J.K. Hamilton, P.A. Rebevs and F. Smith (1956). Colorimetric method for determination of sugars and related compounds. Analy. Chem., 28: 350 356.

El-Deeb, M.A., A. Shahein, M.M. El-Zohairy and A.S. Hassan (1992). Seasonal fluctuations of the citrus red scale insect, Aonidiella aurantii (Maskell) on three citrus tree hosts in Sharkia region. Zagazig. J. Agric. Res., 19 (4): 1879-1895.

El-Nabawi, A. and I.M. Ammar (1987). Population studies on the red scale, Aonidiella aurantii (Mask.) on different citrus hosts in Shebin El-Kom. Bull. Soc. Entomol. Egypt, 67: 1321.

El-Nabawi, A., M.M.A. El-Rahim and M.A. Ammar (1986). Factors affecting the population density of three scale insects on grapefruit trees. Minufiyai. Res., 11: 10251043.

El-Rahman, A., S.M. Metwally and F.M. El-Agamy (1979). Population density and sex ratio of certain scale insects on different citrus hosts at Kafr-El-Sheikh region. J. Agric. Res. Tanta Univ., Egypt, 52: 101-110.

Farag, A., M.M.A. El-Rahim, E.T.E. Darwish and A.M. Zaki (1990). On the abundance of certain insect and mite pests on different citrus varieties. Proc. Int. Conf. Econ. Entomol., 1: 313-324.

Feldman, I. (1956). Use and abuse of $\mathrm{pH}$ measurements. Analyt. Chem., 28 (12): 1859.

Habib, A., H.S. Salama and A.H. Amin (1971). Population studies on scale insects infesting citrus trees in Egypt. Z. Fur Angew. Entomol., 69: 318-330.

Hafez, M., M.F.S. Tawfik and A. Raouf (1970). Fluctuations of the population densities of the black scale, Chrysomphalus ficus Ashm. At. Tech. Bull., 2: 3-16.

Kamel, A.S. (2010). Insects attack citrus trees in Al- Qalyubiyah Governorate, Egypt. Egypt. Acad. J. Biolog. Sci., 3 (2): 107-117.

Morsi, G.A. (1999). Studies on the natural enemies of scale insects infesting some fruit trees. Ph. D. Thesis, Benha Branch, Zagazig Univ., 235.

Moustafa, M. (2012). Scale insects (Coccoidae: Hemiptera) infested citrus trees and their natural enemies, with a key of these pests in Egypt. Egypt. Acad. J. Biolog. Sci., 5 (1): 123.

Salman, A.F. (1970). Studies on the morphology, biology and control of certain coccids in Egypt. M. Sc. Thesis, Fac. Agric., AinShams Univ., Egypt.

Selim, A.A. (1993). Ecological studies on armored scale insects infesting citrus trees (Homoptera: Diaspididae). M.Sc. Thesis, Fac. Agric., AlAzhar Univ., Egypt.

Song, F., R. Gan, Y. Zhang, Q. Xiao, L. Kuang and $\mathrm{H}$. Li (2010). Total phenolic constituents and antioxidant capacities of selected Chinese medicinal plants. J. Mol. Sci., 11: 2362-2372.

Statistics of the Ministry of Agriculture (2014). Statistics of fruit production.

Tawfeek, M.E. (2007). Bioecological studies on some armoured scale insects and their parasitoids. Ph.D. Thesis, Fac. Agric. Alex. Univ., Egypt.

Tawfeek, M.E. (2012). Distributions of armoured scale insects infesting citrus trees in different localities in Egypt. J. Entomol., 9 (6): 429-434.

Turner, T. and B.J. Burri (2013). Potential nutritional benefits of current citrus consumption. J. Agric., (3): 170-187.

Wawrzynski, R.P. and M.E. Ascerno (2009). Scale insects of trees and shrubs; $\mathrm{http} / /$ www.extension.umn.edu/distribution/ho rticulture/dg1019.html. 


\title{
تأثير بعض المكونات الكيميائية لبعض عوائل الموالح على كثافة مجموع الحشرة القشرية الحمراء
}

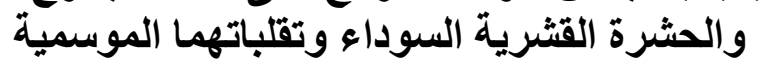

\author{
أسماء محمد عبل الغقار- جميله شحاته سليم - إبر اهيم محمد كيلاني- شادية مصطفى عمارة

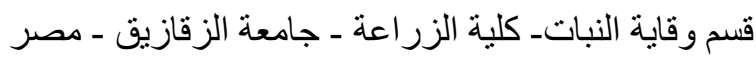

تم إجر اء هذا البحث لار اسة تأثثر بعض المكونات الكيميائية (مركبات الفينول الكلية، الكربو هيدرات الكلية، البروتينات

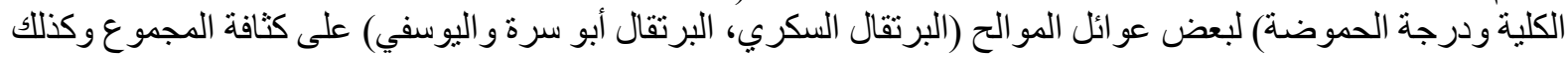

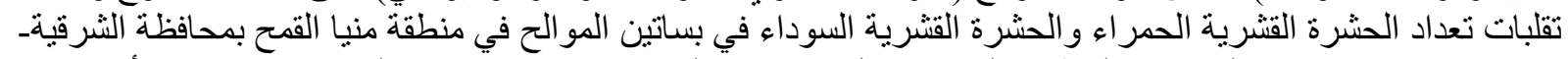

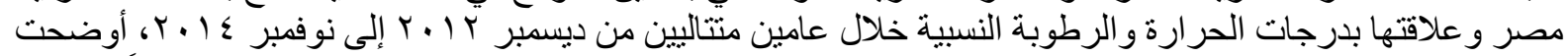

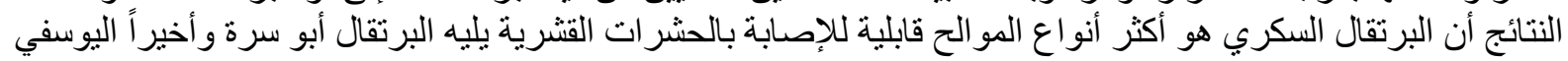

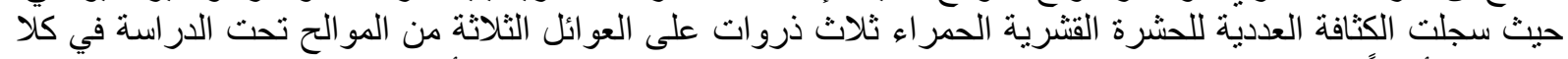

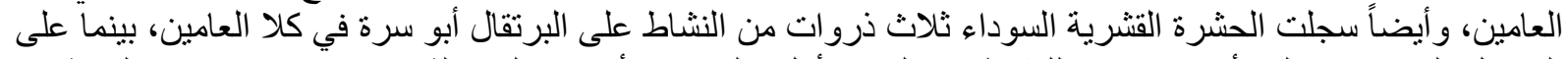

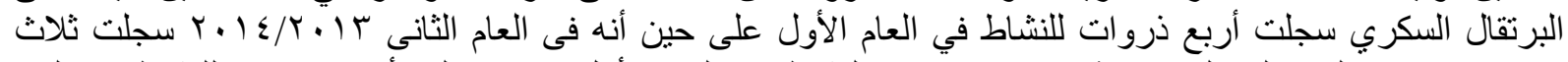

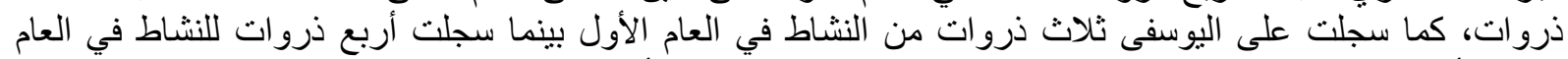

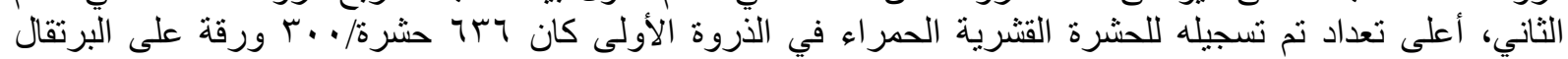

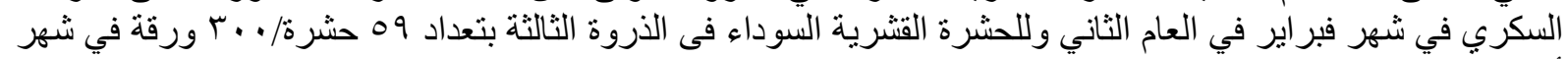

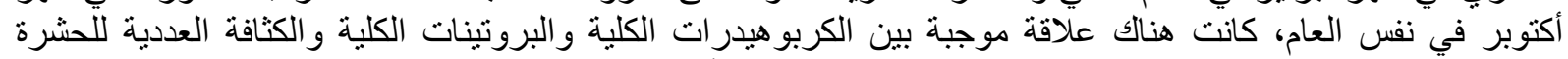

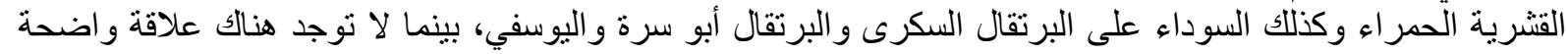

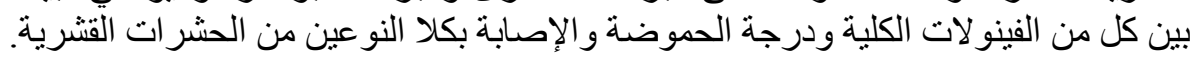

